\title{
A Conceptual Analysis on Development of Rural Villages with Scarcely Resources in Prakasam District, Andhra Pradesh State
}

\section{Khadar Basha Shaik*}

Department of MBA, ABR College of Engineering, Kandukur Road, Kanigiri, Andhra Pradesh, India

\begin{abstract}
Most of the people (nearly 70\%) lived in rural villages. Generally we can't imagine the world without rural villages. So the study explains, development of rural villages with scarcely resources in prakasam dist Andhra Pradesh and explains how to utilization of scarcely resources effectively in rural villages. Rural Development means it is process in all round development of rural area based on scientific utilization of India's natural resources. With this aim, several efforts were made at rural development to better the socio-economic lot of villagers from ancient times to British period. The main objective of the study is to develop the rural villages with available limited resources in prakasam dist Andhra Pradesh state. The purpose of the study is to find out and evaluate the scarcely resources in each every backward rural villages in prakasam dist, AP and work towards to effective utilization of these resources for better development of rural areas. It might be caused for economic growth and economic development of rural villages in the country. After completion of the study we known how to develop rural villages with scarcely resources in prakasam dist, Andhra Pradesh and we get fully awareness and knowledge about scarcely resources in rural areas.
\end{abstract}

Keywords: Scarcely resources; Rural development; Role of government

\section{Introduction}

The rural area means, it is area that has a population of 5000 people or less. Since independence onwards the government has recognized the need to develop rural villages for economic development of the country. For the purpose of the rural development, government of India implemented so many five year plans in the country. It might be caused for the development of income level, industrialization, utilization of resources and creation of employment and others etc. Rural villages are today like this;

- Lack of resources like water, health, education, economic conditions, income, employment opportunities and other infrastructure facilities etc.

- Lack of warehousing facilities,

- Lack of communication facilities and market information, information technology, and its benefits.

- Banks are offered many incentives to rural village's farmers but their rules are very rigid.

Rural Development, it is a process of improving the quality of life and economic conditions of people living in rural villages. In general sense rural development means all round development of social, cultural and economic conditions of the rural people in the country. Our government of India had taken some rural developments actions [1].

Rural Development actions to be taken for the aim of social and economic improvement of the rural villages. Rural development objective is to finding the ways to improve the rural lives to meet the required need of the rural area.

\section{Concept of rural development - scarcely resources}

Rural development meaning all round development of people life's and cities. The definition of rural development varies from one point of view to the other. The rural development may be focused on income criterion in which the concept is made to address the problem of rural poverty. Or it may be defined in sociological concept in which the rural poor represents a reservoir of untapped talent a target group that should be given the opportunity to enjoy the benefits of development through improved education, health and nutrition. This is one of the most important definitions of rural development as the provision of social infrastructures could provide the catalyst.

Rural development is as an ideology concept and practical. Rural development as the improvement in the living standard of the rural dwellers by engaging them in productive activities then will increase their income. Rural development can be differs from agricultural development which it entails and transcends Rural Development may imply re-organization and mobilization of rural masses in order to enhance their capacity to cope effectively with the daily task of their lives. World Bank defined rural development increases production towards increase their incomes. It recognizes that improved food supplies and nutrition, health and education, not only improve the physical well-being, quality of life of the rural poor and productivity level, also and their ability to. It is concerned with increased agricultural production for urban and international markets. To encourage increased production rural development may offer a package of inputs and welfare services for the rural masses. Such inputs and welfare services include physical inputs (such as the provision of feeder roads, water and electrification), social inputs, agricultural research facilities, rural expansion services among others [2].

Meaning and concept: The term rural development has changed significantly during the last three decades. From untile the 1970's, rural development was used as synonymous with agricultural development

${ }^{*}$ Corresponding author: Khadar Basha Shaik, Assistant Professor, Department of MBA, ABR college of Engineering, Kandukur road, Kanigiri, Prakasam District, Andhra Pradesh, India, Tel: 9440988148; E-mail: khadarbasha148@gmail.com

Received June 05, 2017; Accepted June 26, 2017; Published June 28, 2017

Citation: Shaik KB (2017) A Conceptual Analysis on Development of Rural Villages with Scarcely Resources in Prakasam District, Andhra Pradesh State. Int J Econ Manag Sci 6: 439. doi: 10.4172/2162-6359.1000439

Copyright: (c) 2017 Shaik KB. This is an open-access article distributed under the terms of the Creative Commons Attribution License, which permits unrestricted use, distribution, and reproduction in any medium, provided the original author and source are credited. 
and hence focused on increasing agricultural production. Rural development has begun to be used in a broader sense. It is mainly focused and includes the income related factors such as prices, production, and productivity etc. rural development covers three inter related dimensions.

- Economic Dimension

- Social Dimension

- Political Dimension

1. Economic Dimension providing capacity and opportunities for the poor and low-income households in particular ill benefit from the economic growth.

2. Social Dimension, it supports the social development of lowincome households and poor people. Promotes gender inequalities and women empowerment and provides social safety facilities for group of people.

3. Political Dimension increases the opportunities for the poor and low income people in rural areas (Figure 1).

\section{Objectives of Rural Development}

- To improve the living standards by providing food, shelter, clothing, employment and education.

- To reduce poverty and providing productivity in rural areas.

- To involve people in planning and development through their participation in decision making and through centralization of administration.

- To ensure distributive justice and equalization of opportunities in the society.

\section{Strategies in rural development}

Strategy in the sense ordering of various policy parameters to attain the certain goals. Different strategies consists different importance in order to achieve the goals of rural development. The following mentioned the various types of strategies to agrarian relations for purpose of classification.
1. A stratgey based on collectivization of resources

2. A strategy based on regulated capitalist perspective

3. A strategy based on peasant agrarian perspective

4. A strategy based on Laissez -Faire or un-regulated free market capitalist perspective [3].

\section{A stratgey based on collectivization of resources}

Collectivization of rural assets particularly land is given almost importance in the first strategy. Private ownership of land is collapsed so that not only inequalities in the ownership of land are eliminated but also land use can be made more productive.

\section{A strategy based on regulated capitalist perspective}

This strategy reveals the capitalist sector and a peasant sector that gets same support and protection from the state. It has beenpointed out that without meanigful land reforms. It is a great portion of rural credit disursed though co-operative institutions has gone into the hands of those who are better off and have the capacity to mobilize their own resources.

\section{A strategy based on peasant agrarian perspective}

The strategy based on the peasant agraraian perspective argues for through going redistribution of land and overhaul of land relations. It is expected to perform a whole range of important functions.

\section{A strategy based on Laissez -Faire or un-regulated free market capitalist perspective}

The strategy explains the rich landowners will play the important role in rapid increase in agricultural output,by taking advantage of the conomics of scale and gradually the small cultivation units will disapper. The issues of inequality and distributive justice are considered non issues in such a strategy.The core group of rural development strategy may be listed here as follows:

1. Agricultural research ,extension rural education and training programmes for farmers form a part of institution building activities.

\section{THREE DIMENSIONS OF INCLUSIVE RURAI DEVELOPMENT}

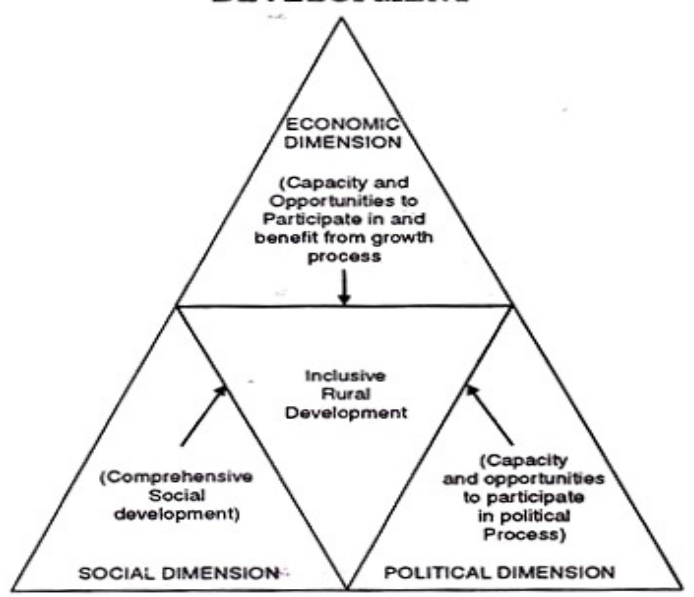

Figure 1: Three dimensions of rural development. 
2. Infrastructure building activity related to the growth of irrigation, transport, communications and health facilities.

3. Programmes to improve marketing facilities for the distribution of agricultural inputs and implements etc.

Agricultrual sector can also be classified as un-modal and bi-modal strategies.

Uni-modal strategy: A uni-modal strategy is one in which land holdings arc equitably distributed. This strategy was followed with tremendous success in the case of japan, taiwan and korea. It seeks to pormote rural development through the use of through going reforms in the agricultural sector. The agricultural strategy creates that rapid growth of agricultural production with equitable distribution of incomes. The might be causes for economic development of the coun try.

The bi-modal strategy: The strategy for the growth of the agricultural sector to increase agricultural production without making attempts to increase agricultural production without making attempts to change the skewed distribution of incomes and assets in rural areas. The idea of modern technology creates towards overall development of the economc growth.

There are so many problems facing rural areas in today's world. These problems are:

- Drinking water problems

- Agricultural related problems

- Drainage problems

- Poor sanitation problems

- Food and employment problems

- The Migration of young people, for employment, work and other sources.

- Indiscriminate use of pesticides and fertilizers problems

- Miscellaneous problems- non availability of information related to agriculture, roads and transported.

\section{Importance of Rural Development and Government role}

Day by day rural development importance increases because most of the people live in rural villages nearly $70 \%$. That is the reason government of India also give importance for development of rural villages. From since independence onwards our government of India implemented so many programmes and schemes for rural villages' development. For example: MGNREGS, PMGSY, SAGY, IAY, PMDJY, insurance schemes for health, aarogya raksha etc. when rural areas are developed automatically urban cities, towns also developed then we get economic growth and development of the country. Government of AP also implemented some schemes for rural villages like aarogaya raksha, velugu padhakam, bicyle for girl student's scheme, health insurance schemes, Mid day meals scheme etc. for the purpose of rural village development present our central government and state government also allocated budget Rs. 1, 87,223/-crore (34.58\%) +19,565/-crore. Dependent on this information we can said that rural development importance increases rapidly in the country.

The government of India also gives most important for rural sector because rural people live in rural villages without having minimum needs and other facilities also. The behind this reason state and central governments also give most important for all round development of the villages. For the rural development purpose our governments are allocating huge budget as well as take development actions in all aspects [4]. Finally not only our government of AP and central government all other countries also give importance to rural development.

\section{Scarce resources - meaning}

In general term scarce resources means barely, narrowly available resources in rural areas. Commonly available limited resources in rural areas are water, electricity, food and forests etc. The scarce resources can be defined as the resources almost not at all or certainly not.

\section{Definition - scarce resources}

Scarce resources, it is very difficult to define and express the meaning of it. But this scarce or limited resource plays a pivotal role in nowadays. Because the human beings wants and needs are increases day by day, for this achievement or satisfaction of these needs the people using so many resources. So the resources are might be scarcely in all aspects. The following are the main natural resources. These are;

- Water

- Oil

- Coal

- Rare earth elements

- Natural gas etc.

Scarcity in the sense few resources: It is the main basic economic problem of the country for Indian economy.

Example of scarcity was:

- In prakasam district, donakonda mandal, we have huge acres of government land but not use of this land because scarcity of electricity and water etc.

\section{Discussion of the study}

The study explains development of rural villages with scarcely resources in prakasam dist Andhra Pradesh state. For this study we selected one of the district of Andhra Pradesh states that are prakasam dist Andhra Pradesh state. The head quarter of prakasam district was Ongole. Ongole famous for ongole bulls generally called for "ongole Gitta". In this district total population 33,92,764 (2011 census base), total 56 mandals, three revenue divisions i.e. kandukur,ongole and markapur divisions, 1093 villages, 13 towns, one municipal corporation, 3 municipalities and 4 nagara panchayats are there. The main scarce resource of the district was ground water level. In prakasam district one of the mandal is giddalur, in this mandal the ground water level fallen by 2.45 meters to 18.23 meters during the March month of this year. This mandal was very worst affected ground water level plummets to a precarious low in prakasam dist. These type of affected mandals are there in prakasam dist. i.e. dornala, yerragondapalem, racheral, peddaraveedu, markapuram etc. our AP government CM sri Nara Chandra Babu Naidu garu visited to giddalur mandal for control the present trends and situations of groundwater level, for this reason one programme was implemented that is "NEERU CHETTU". Like this so many scare resources are there in prakasam i.e. unemployment, education, roads \& transport etc. in some villages [5]. The study mainly emphasized if we using these scarce resources for better way for example in prakasam dist ground water plummets level decreasing day by day. So we have to construct alternative dug wells, canals and other storage facilities in drought areas. After using 
of this ground water then we have to moves that water for other usage like crops cultivation, for animals to drinking etc. The government of $\mathrm{AP}$ also takes some precautions to control the falling of ground water level in the earth. Finally if we construct or establish low consuming scarce resources related companies, manufacturing units, small scale industries in prakasam dist and at the same time we have to utilize resources in better way automatically we can get economic growth and economic development of the country.

Village industry programmes: The following are the some village industries in drawn up by the planning commission in consultation with a number of experts.

- Village oil industry

- Soap -making with neem oil

- Paddy husking

- Leather industry

- Auto Mobile industry

- Air space spare parts making industry etc.

Village industries: Village industries have a central place in rural development programmes. Their occupations now give them only partial employment, so that they tend to join the ranks of agricultural workers. Development outside the rural sector has not been rapid [6] enough to arrest the increasing pressure of population on the land. Therefore, it will develop a great deal of local initiative and co-operation, and an economic environment in which they have a reasonable chance of succeeding. If the measures to be undertaken are to be effective in dealing with so difficult a problem, it is essential that they should be commensurate with its size and importance.

\section{Findings}

1. In prakasam dist, most scarce resource is fallen of ground water level in giddalur village.

2. Non availability of employment resources, education, transport facility, and other development activities etc.

3. Government development schemes not implemented proper way in prakasam dist as well as not if availability government schemes not using people proper way. Example livelihood projects, skill development activities etc. $[7,8]$.

4. Government of AP State not caring of this district proper way.

\section{Suggestions}

The study gives some suggestions/Recommendations for controlling of fallen by ground water level in backward area villages in prakasam district in Andhra Pradesh.

- Take some control precautions under government of AP as well as central government in giddalur village, prakasam dist. Provide alternative facilities in these villages like digging canals, dug wells and other storage water facilities etc

- Effective utilization of rainy water for future use.

- Providing proper education facilities, employment, development activities in affective and efficient manner under state government in this district through proper channel.

- Taking serious actions for implementing of government development schemes in this district under appointment of one committee supervisor and government authorities in this district.

- To conduct benefits and utilization of schemes awareness programmes whole of this district.

- Proper utilization of available resources in efficient and future purpose also etc.

- Government of AP should take into consideration for development of this district in all aspects and one more suggestions is ;

- Don't remove of plants and don't collapse of mountains, big rocks etc, if we collapse these things they will be collapse us through in the form of scarcely resources.

\section{Conclusion}

Allocatation of limited, scarcely resources in rural areas are always difficult, because in rural areas they don't know knowledge about scarce resources, how to use scarcely resources and what are the problems are faced in future without having scarcely resources especially in seasons.

I conclude that the study mainly emphasized on scarcely resources prakasam dist, and Andhra Pradesh state. Now days scarcely resources plays an important role because human being used for most of the resources $[9,10]$ for satisfying their needs and wants and development purpose. Basic of that reason resources become scarcely. Hence the study mainly focused on scarcely resources for development of rural villages. After completion of the study we can get the full knowledge about scarce resources, what is rural development, rural area problems etc in rural villages. Finally, the study told that how to anticipating allocation and effective utilization of scarce resources for all round development of the rural villages in Andhra Pradesh [11].

\section{References}

1. Monizuzzaman Md (2002) Loan Utilization pattern of Bangladesh Rura Development Board [BRDB] Women Cooperatives and Grameen Bank [GB] Groups: A Comparative Analysis. Journal of Rural Development 21: 67-84.

2. Namasivayam D, Ramachandraiah G (2000) End-use of Credit and Repayment Performance of the Institutional Borrowers: An integrated analysis. Journal of Rural Development 19: 411-429.

3. Chigbu UE (2012) Village Renewal as an instrument of Rural Development Evidence from Weyam Germany. Community Development 43: 209-224.

4. Moseley MJ (2003) Rural development: principles and practice. Sage publications Itd, London, UK.

5. Anil K (2016) Rajvanshi road map for Rural India. Current Science 111: 39-45.

6. Ministry of rural development (2007) government of India chap-7, rural development, pp: 88-99.

7. Planning commission, Government of India, $12^{\text {th }}$ five year plan (2012-2017) vol. 3 , inclusive growth.

8. George PT (1984) Repayment Performance by farmers in Chenglepet District [Tamilnadu]. Journal of rural development, 3, No. 3, May. Goiporia MN, 'New Dimensions in Banking', State Bank.

9. Balister (1989) Agricultural loans: menace of over dues. Yojana 33, No.13.

10. Balister (1984) Primary Agricultural Credit Cooperatives in UP: their progress, performance and problems. Indian Cooperative Review 22.

11. Beal GM, Sibey PN (1967) Adoption of Agricultural Technology by the Indians of Gautemela, Rural Sociology Report-62, lowa State University. 